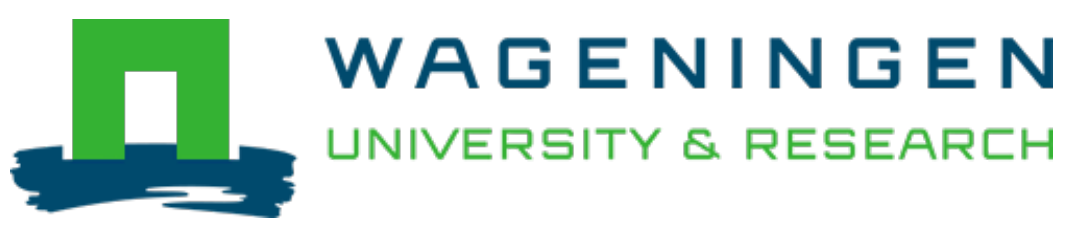

\title{
The impact of training and monitoring on loan repayment of microfinance debtors in Ghana
}

\author{
Journal of Behavioral and Experimental Finance \\ Agbeko, Daniel; Blok, Vincent; Omta, S.W.F.; Velde, G. \\ https://doi.org/10.1016/j.jbef.2017.03.002
}

This article is made publicly available in the institutional repository of Wageningen University and Research, under the terms of article $25 \mathrm{fa}$ of the Dutch Copyright Act, also known as the Amendment Taverne. This has been done with explicit consent by the author.

Article 25 fa states that the author of a short scientific work funded either wholly or partially by Dutch public funds is entitled to make that work publicly available for no consideration following a reasonable period of time after the work was first published, provided that clear reference is made to the source of the first publication of the work.

This publication is distributed under The Association of Universities in the Netherlands (VSNU) 'Article $25 \mathrm{fa}$ implementation' project. In this project research outputs of researchers employed by Dutch Universities that comply with the legal requirements of Article $25 \mathrm{fa}$ of the Dutch Copyright Act are distributed online and free of cost or other barriers in institutional repositories. Research outputs are distributed six months after their first online publication in the original published version and with proper attribution to the source of the original publication.

You are permitted to download and use the publication for personal purposes. All rights remain with the author(s) and / or copyright owner(s) of this work. Any use of the publication or parts of it other than authorised under article $25 \mathrm{fa}$ of the Dutch Copyright act is prohibited. Wageningen University \& Research and the author(s) of this publication shall not be held responsible or liable for any damages resulting from your (re)use of this publication.

For questions regarding the public availability of this article please contact openscience.library@wur.nl 
Full length article

\title{
The impact of training and monitoring on loan repayment of microfinance debtors in Ghana
}

\author{
Daniel Agbeko ${ }^{\mathrm{a}, *}$, Vincent Blok ${ }^{\mathrm{b}, \mathrm{c}}$, S.W.F. Omta ${ }^{\mathrm{d}, 1}$, G. Van der Velde ${ }^{\mathrm{d}, 1}$ \\ a University of Wageningen, The Netherlands \\ ${ }^{\mathrm{b}}$ Management Studies Group, School of Social Sciences, Wageningen University, The Netherlands \\ ${ }^{c}$ Wageningen University, Hollandseweg 1, 6707 KN Wageningen, The Netherlands \\ d Wageningen University Management Studies, de Leeuwenborch, building 201, Bode 77Hollandseweg 16706 KN Wageningen, The Netherlands
}

\section{A R T I C L E I N F O}

Article history:

Received 3 October 2016

Received in revised form

10 March 2017

Accepted 30 March 2017

Available online 7 April 2017

Keywords:

Training programmes

Entrepreneurship

Microfinance

\begin{abstract}
A B S T R A C T
Microbusiness entrepreneurs training and monitoring programmes are widely recognized as key to loan repayment performance of microfinance institution (MFI) loan clients in developing countries. Empirical evidence is, however, largely lacking and where present, not consistent. The present paper introduces objective data on loan repayments and examines whether loan client training and monitoring improve loan repayment rates. We conducted a two-step longitudinal survey. We collected baseline data on 229 uniCredit Ghana Limited MFI loan client files. One and half years later, after having introduced training and monitoring interventions, follow-up data on the same loan clients were collected. Results showed that training interventions fail to improve loan repayment rates. Strikingly, client monitoring does improve repayment rates, irrespective of the clients' educational level, business experience or gender. These results suggest that MFI's may significantly improve repayment rates should they consistently monitor their loan clients.
\end{abstract}

(C) 2017 Elsevier B.V. All rights reserved.

\section{Introduction}

In developing countries, microfinance institutions' (MFI) microfinance debtor repayment rates typically fall short and jeopardize sustainability of both MFIs and microbusinesses. Entrepreneurship training and microfinance debtor monitoring programmes may improve microbusinesses performance and, therefore, loan repayment rates. Empirical evidence remains, however, inconclusive.

As to entrepreneurship training, the human capital theory asserts that those individuals endowed with knowledge, skills and competencies perform better in executing relevant tasks (Becker, 1993; Kraiger et al., 1993; Ployhart and Moliterno, 2011). Entrepreneurship training may improve microbusiness performance and, therefore, loan repayment rates (Edgcomb, 2002; Karlan and Valdivia, 2011; Lensink et al., 2011). Empirical studies however fail

\footnotetext{
* Corresponding author.

E-mail addresses: daniel_agbeko@yahoo.com (D.Agbeko),vincent.blok@wur.nl (V. Blok), onno.omta@wur.nl (S.W.F. Omta),g.vander.velde@windesheim.nl (G. Van der Velde).

1 Fax: +310317485454
}

to establish that entrepreneurship training programmes systematically improve microbusiness performance (Karlan and Valdivia, 2011; McKenzie and Woodruff, 2012).

Microfinance debtor monitoring may be instrumental for preventing loan diversion, improving the relation between MFI and microbusiness entrepreneur and mitigating information asymmetry between lender and borrower (Behr et al., 2011; Edgcomb, 2002; Kohansal and Mansoori, 2009). Though widely recognized, in the literature there is no empirical evidence on the effectiveness of monitoring for improving loan repayment rates.

The objective of the present paper is to empirically establish whether entrepreneurship training and microfinance debtor monitoring programmes improve MFI microfinance debtors' repayment rates. We advance on the literature in two dimensions. First, the present paper is the first to empirically examine whether those microfinance debtors who were monitored systematically improve loan repayment performance. Second, we improve on the research design. As opposed to previous literature, we compare a baseline study with one and half year follow-up repayment rates, after having introduced training and monitoring interventions. This longitudinal research design better allows for examining the advantages of training and monitoring programmes. As opposed to previous studies, we rely on MFI microfinance debtor files and 
collect objective loan repayment data. Results show that training programmes do not improve loan repayment rates; microfinance debtor monitoring programmes prove advantageous.

In Section 2 we discuss literature on entrepreneurship training and monitoring. Section 3 presents the data and methods. Section 4 provides the results. Section 5 concludes.

\section{Entrepreneurship training and monitoring programmes}

Consistent with human capital theory, various studies argue that entrepreneurial and business competencies improve entrepreneurial performance (Baron and Ensley, 2006; Baum and Locke, 2004; Chandler and Jansen, 1992; Newman et al., 2014; Ucbasaran et al., 2008). Entrepreneurship training may help microbusiness entrepreneurs use microfinance more effectively (Ekpe et al., 2010; Idris and Agbim, 2015; Karnani, 2007) and, therefore, alleviate their poverty (Karlan and Valdivia, 2011; Mutisya and Yarime, 2014).

Lensink et al. (2011) use data from 61 countries and empirically establish that those microfinance debtors who participate in training programmes improve on their business performances and repay their loans better. Echtner (1995) considers entrepreneurship programmes the most cost effective means of educating and empowering individual entrepreneurs.

Others argue that training programmes fail to effectively improve microfinance debtors' repayment rates (Karlan and Valdivia, 2011) do not find any effect of training programmes participation and conclude that training may improve performance of only few programme participants. McKenzie and Woodruff (2012) empirically establish that training programmes typically have only small positive effects on business practices and do not significantly improve sales nor profitability. More generally, Yunus (1999) argues that entrepreneurial skills are innate and therefore cannot be trained.

Microfinance debtor monitoring programmes involve MFI loan officers to continuously monitor their debtors' business performance, provide tailored and informal on site business advice and help entrepreneurs access business related networks. Balogun and Alimi (1988) and Ledgerwood (1999) consider poor monitoring practices a major cause of loan defaults. At the individual level, effective monitoring requires loan officers to acquire specific entrepreneurial and coaching competencies. At the institutional level, MFIs need organizational structures specifically designed to facilitate this process of monitoring. Lensink et al. (2011) conclude that those MFIs that continuously monitor their debtors have better performance than those MFIs that provide financial services only. Bichanga and Aseyo (2013), Elaine and Barton (1998) and Godquin (2004) conclude that non-financial services such as primary health, basic literacy, market information and informal occupational and business skills training positively influence business performance. Kohansal and Mansoori (2009) and Mensah et al. (2013) argue that monitoring helps prevent loan diversion. Edgcomb (2002) and Elaine and Barton (1998) state that provision of non-financial services such as business monitoring deepens the relation of the debtors with the MFI. Monitoring is instrumental for motivating debtors to repay loans promptly (Mirpourian et al., 2015). Behr et al. (2011) argue that monitoring helps mitigate information asymmetry between lender and borrower and, therefore, improves loan repayment rates. Following Kuzilwa (2005), training and monitoring should be considered a joint effort.

\section{Methods}

Studies on the advantages of entrepreneurship training typically rely on cross section data and therefore cannot adequately

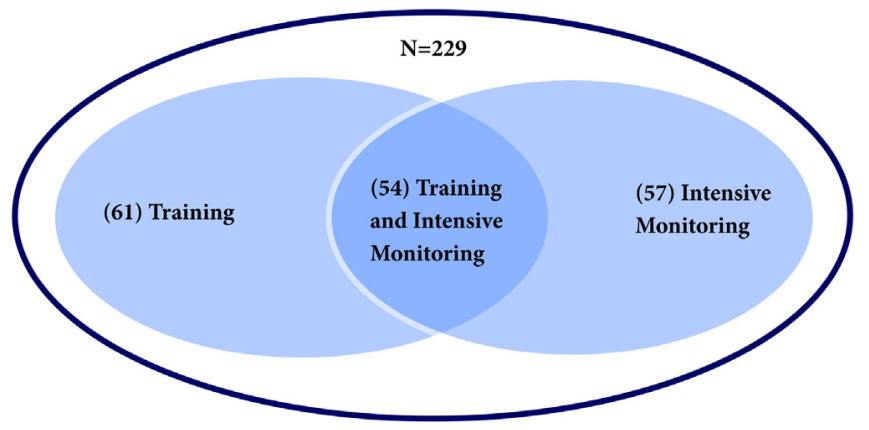

Fig. 1. Total sample strata, by intervention.

assess the advantages of training programmes. This leaves the results of most studies unreliable (Martin et al., 2013). The present paper advances on these studies and examines the impact of training and monitoring interventions by conducting a two-step longitudinal approach. We collected baseline data on 229 microfinance debtors. One and half year later, after having introduced training and monitoring interventions, we collected follow-up data on these 229 debtors. This study design better allows for examining our research question: What is the impact of training and monitoring programmes on loan repayment rates of microfinance debtors?

The study site for this research is a Ghanaian MFI, where the first author of this paper has been employed as manager. This allowed for access to loan repayment data. The primary focus of the MFI is to provide financial services that are specifically tailored towards the needs of micro, small and medium scale enterprises.

The mission of the MFI case is to develop easily accessible financial products. As of 2011, the MFI had twelve branches, with an institutional deposit of USD 39 million deposited by 71 thousand customers and loans portfolio of USD 24 million with 3, 5 thousand microfinance debtors (Mix-Market, 2015). The loans portfolio is categorized into three categories. The first is the corporate loans category with business loans larger than USD 50 thousand. It accrues to $30 \%$ of the total loans portfolio, and shows repayment rates above $85 \%$. The second category is the business loans sector with loans ranging from USD 4 thousand to USD 50 thousand. This category equals $38 \%$ of the loans portfolio and shows a $77 \%$ repayment rate. The third category comprises of microloans below USD 4000 . This category constitutes $32 \%$ the MFI loans portfolio of loans and shows a 50\% repayment rate. Loan repayment is defined as full repayment of principal and interest before due date, on due date, or seven days past due date.

For our case analysis, the entire loan list was downloaded and microfinance debtors with loan disbursements above USD 4000 were excluded as these microfinance debtors cannot be considered microfinance debtors. Staff loans and salary workers loans were also excluded. From the microfinance debtors loan portfolio, 235 were randomly selected from the total data on 3277 debtors and included in the baseline database. Baseline data were collected in April, 2013. After having introduced the interventions, we collected follow-up repayment data in October, 2014. For 229 respondents we had data on loan repayments at both baseline and follow-up date, leaving the sample size at 229 observations. Loan officers then randomly invited $25 \%$ or 60 microfinance debtors to participate in either of the four interventions; no intervention, monitoring, training, or both monitoring and training.

\section{The training intervention}

Following Bichanga and Aseyo (2013), Elaine and Barton (1998), Kohansal and Mansoori (2009), Mensah et al. (2013), Lensink et al. (2011) and Echtner (1995), entrepreneurial and business skills may improve business performance and, therefore, loan repayment rates. In total 115 microfinance debtors were trained, see Fig. 1. 
These 115 microfinance debtors participated in a five days training programme aimed at developing entrepreneurial and business skills. The training was organized in five batches to maximize debtor participation and understanding. The impact of the training may depend on the skills, experience and qualifications of the trainer. For this training intervention we therefore hired a professional trainer associated with Freedom from Hunger, a United Nation based non-profit organization. Freedom from Hunger is widely recognized as leader in credit-with-education programmes and is responsible for training interventions in eighteen countries and over 50 financial institutions and 700,000 trainees (Karlan and Valdivia, 2011). To ensure maximum participation the training was provided in the Ghanaian local language Twi. Microfinance debtors were trained in three main modules, the first two of which lasted for two days each, the last module lasted for a day, see Appendix 1.

The first training module focused on building business operations skills. These include general business planning, record keeping and financial management skills. General business planning skills involve short term planning and budgeting skills (Smith and Perks, 2006; Van Dyk et al., 1992). Record keeping skills include book keeping and inventory management skills (Edgcomb, 2002; Karlan and Valdivia, 2011; Mano et al., 2012; Van Dyk et al., 1992). Financial management skills relate to the ability to design the income statement (Edgcomb, 2002; Karlan and Valdivia, 2011; Mano et al., 2012; Smith and Perks, 2006).

The second training module aimed at acquiring entrepreneurial skills. These include the willingness to take risks and be innovative and pro-active (Verhees et al., 2012; Wiklund et al., 2009). As to the willingness to take risk, the trainer followed Chen et al. (1998), Oosterbeek et al. (2010) and Verhees et al. (2012) and discussed issues of accountability, decision making under pressure and the use of check list procedures. Consistent with Chen et al. (1998) and Verhees et al. (2012), training on innovativeness involved discussions on how to introduce new products and services and how to explore new markets and methods of production. The debtors' proactiveness is trained by means of discussions on the willingness to start a new activity, to be the first to respond to new opportunities, and the debtors' proficiency with starting new activities (Verhees et al., 2012). The second training module followed Smith and Perks (2006) and Van Dyk et al. (1992) and emphasized the need to maintain customer relations and interpersonal relations.

The third training module discussed market orientation skills and focused on how to set sales, profit and market share objectives. The relevance of market orientation skills for microbusiness performance is argued for by, among others, Alby et al. (2011), Chen et al. (1998), Edgcomb (2002), Oosterbeek et al. (2010), OteroNeira et al. (2013) and Verhees et al. (2012).

\section{The monitoring intervention}

The MFI typically monitors its microfinance debtors at an average of four times per year. For our monitoring intervention we intensified the monitoring frequency from four to 24 times per year. In total 111 microfinance debtors were monitored, see Fig. 1. These microfinance debtors were assigned to the loan officers, 11 per the first loan officer and 10 per all the other officers. The loan officers were tasked to visit every single debtor on site, twice per month for 18 months starting from April 2013 to October 2014. To minimize cost per visit, the locations of the debtors were zoned based on proximity of the sales locations of other debtors, such that debtors who were close to each other were visited on the same day. The monitoring involved discussing business challenges faced by the debtor. The officers informally advised the individual debtors on how to improve their businesses methods, introduced the debtors to specific business networks, supported debtors to get involved in relevant supply chains and shared local financial and economic news.

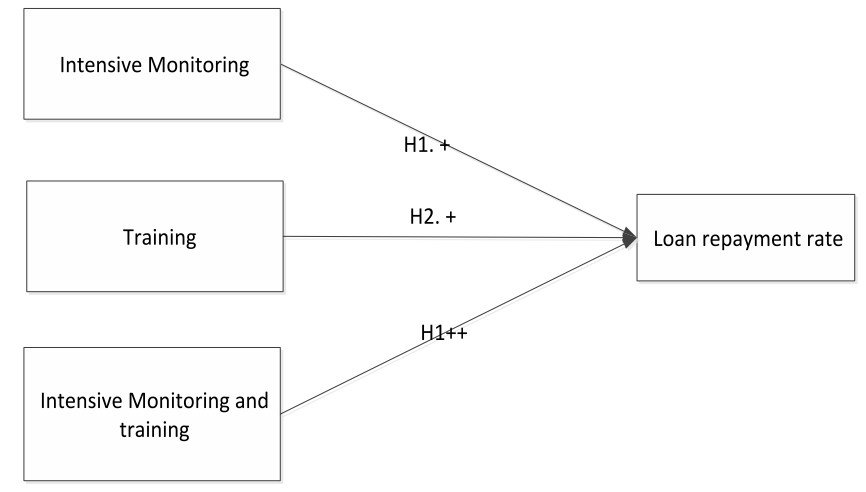

Fig. 2. Intensive monitoring, training and loan repayment rate.

Following Echtner (1995), Kohansal and Mansoori (2009), Lensink et al. (2011), Mensah et al. (2013), Bichanga and Aseyo (2013), Elaine and Barton (1998) and Mensah et al. (2013), we examine the extent to which training and monitoring programmes improve loan repayment rates of MFIs microfinance debtors. Following Kuzilwa (2005), training and monitoring interventions should be considered a joint effort. More specifically, we hypothesize that:

H1. Improvements in repayment rates across time are more pronounced for those microfinance debtors who are monitored intensively, relative to those debtors who are neither trained nor monitored.

H2. Improvements in repayment rates across time are more pronounced for those microfinance debtors who participate in entrepreneurship training programmes, relative to those debtors who are neither trained nor monitored.

H3. Improvements in repayment rates across time are more pronounced for those microfinance debtors who are both trained and monitored intensively, relative to those debtors who are trained only or monitored only.

(see Fig. 2)

According to Lans et al. (2015), business experience matters for business performance. The human capital theory postulates that education and work experience add to successful entrepreneurship (Martin et al., 2013). Based on this theory, Becker (1993), Kraiger et al. (1993) and Ployhart and Moliterno (2011) assert that individuals or groups with experience and knowledge perform better in executing relevant tasks. Based on cluster analysis of the 229 microfinance debtors sample, not shown here, we established that those microfinance debtors with tertiary degrees or more than 15 years business experience show significantly higher repayment rates. In our assessment of the efficacy of training and monitoring interventions we therefore distinguish those with more than 15 years of business experience and those with tertiary education from the less experienced and those with primary or secondary degrees only.

Women tend to manifest behaviours that can best be described as social, friendly and risk averse, more than do men (Anthony and Horne, 2003). Female microfinance debtors repay their loans better than do male entrepreneurs (Anthony and Horne, 2003; Kabeer, 2001; Kevane and Wydick, 2001; Ledgerwood, 1999; Pronyk et al., 2008; Rahman, 1999; Ridgeway and Smith-Lovin, 1999). In our assessment of the efficacy of monitoring and training interventions we therefore distinguish between male and female entrepreneurs. 
Table 1

Descriptives: loan repayment rates at baseline and follow-up date.

\begin{tabular}{|c|c|c|c|}
\hline & Number of microfinance debtors & Baseline repayment rate & Follow-up repayment rate \\
\hline Total sample & 229 & 0.45 & 0.65 \\
\hline No intervention (control group) & 57 & 0.42 & 0.23 \\
\hline Intensive monitoring & 57 & 0.42 & 0.93 \\
\hline Training & 61 & 0.56 & 0.46 \\
\hline Intensive monitoring and training & 54 & 0.41 & 0.96 \\
\hline \multirow{2}{*}{ Education } & 203 (prim \& sec) & 0.46 & 0.65 \\
\hline & 26 (tertiary) & 0.42 & 0.59 \\
\hline \multirow{2}{*}{ Business experience } & 166 ( <15 years $)$ & 0.46 & 0.64 \\
\hline & 63 (>15 years) & 0.43 & 0.67 \\
\hline \multirow{2}{*}{ Gender } & 129 (female) & 0.50 & 0.63 \\
\hline & 100 (male) & 0.39 & 0.66 \\
\hline
\end{tabular}

\section{Results}

The 229 total sample overall repayment rate is $45 \%$, see Table 1. During the one and half year time span between baseline and follow-up date, overall repayment rates have increased 20 percentage points from baseline performance. The 57 control group microfinance debtors show a $42 \%$ repayment rate at baseline date. These entrepreneurs are monitored four times per year on average. This monitoring frequency is typical for MFIs. For these 57 control group microfinance debtors this monitoring frequency is left unchanged. In the absence of any interventions, control group repayment rates decreased considerably over time, underlining the need for interventions. The substantial decrease in repayment rates may be explained by significant increases in inflation rates and the macro economic downturn during the time span. As opposed to those 57 control group debtors that were neither monitored intensively nor trained, those 57 microfinance debtors that were monitored intensively show improved repayment rates. Relative to monitoring, training programmes prove less advantageous.

More generally, the pronounced differences between baseline and follow-up statistics underline the need for distinguishing within-effects (time effects) from between-effects (effects of interventions for different sample strata) when assessing the advantages of training and monitoring programmes. The pronounced differences across both time and sample strata also suggest interactions between time and intervention: Systematic changes in repayment rates over time may differ for particular interventions.

Using repeated measures ANOVA procedures, repayment rates for those microfinance debtors who were trained or monitored intensively are compared to repayment rates for those microfinance debtors who did not receive any intervention during the baseline and follow-up time frame (see Table 2). Results hold for repeated measures logit procedures, available upon request from the authors.

For those microfinance debtors neither trained nor monitored, loan repayment decreased from 42 to $23 \%$ within one and half years after baseline date, indicating deterioration of loan repayment by 19 percentage points, see Table 2 . This decrease is statistically significant (paired-samples $t$-statistic, $p$-value $=0.01$, not shown here).

For those microfinance debtors who were monitored intensively, average repayment rate across the 18 months' time frame is $68 \%$ and significantly different from $33 \%$ control group repayment rate $(F$-statistic $=41.41, p$-value $=0.01)$, see Table 2, Model 1 .

Monitored debtors' repayment rates improved from $42 \%$ to $93 \%$ at follow-up date. This 51 percentage points improvement is statistically significant $(F$-statistic $=7.05, p$-value $=0.01)$. This 51 percentage point improvement is different from control group dynamics $(F$-statistic $=34.84, p$-value $=0.01)$. Improvement over time is more pronounced for those debtors who are monitored: Intensive monitoring improves repayment rates.
Those microfinance debtors who were trained showed a $51 \%$ average repayment rate between baseline and follow-up date, see Model 2. Although this cross period repayment rate is better than $33 \%$ control group average repayment rates $(F$-statistic $=9.23$, $p$-value $=0.01)$, trained debtors decrease repayments from 56 at baseline date to only 46 for every 100 loans at follow-up date $(F$-statistic $=4.98, p$-value $=0.03)$. This decrease in repayment rate over time is not different from control group dynamics $(F$-statistic $=0.52, p$-value $=0.47)$. Training programmes fail to mitigate the control group trend of decreasing repayment rates over time.

Repayment rates for those microfinance debtors who were both trained and monitored are compared to repayment rates for those microfinance debtors who were intensively monitored, see Model 3. This allows for examining interaction effects between training and monitoring interventions. Results show that the combination of training and intensive monitoring is only marginally better than intensive monitoring only, suggesting that training programmes do not add to intensive monitoring programmes.

Education, business experience and gender may influence the efficacy of monitoring interventions, see Table 3.

Those debtors with tertiary degrees do not repay their loans any better than those with primary and secondary education only (F-statistic $=0.02, p$-value $=0.89)$, see Table 3, Model 4. Both these 49 poorly and 8 highly educated entrepreneurs improved upon their repayment performance over time ( $F$ statistic $=15.45, p$-value $=0.01$ ). This result suggests that intensive monitoring is as effective for those with primary and secondary education as well as for those with tertiary degrees $(F$-statistic $=0.46, p$-value $=0.50)$.

Those debtors with more than 15 years of business experience repay their loans better than do less experienced entrepreneurs $(F$-statistic $=3.19, p$-value $=0.08)$, see Model 5. Both these 45 unexperienced and 12 experienced entrepreneurs improved upon their repayment performance over time $(F$-statistic $=23.38$, $p$-value $=0.01$ ). Intensive monitoring is equally effective for those with and without business experience $(F$-statistic $=0.35$, $p$-value $=0.56$ ).

Between baseline and follow-up date, average repayment rates for females equal those for males $(F$-statistic $=0.87$, $p$-value $=0.36$ ), see Model 6 . Both female and male entrepreneurs improved upon their repayment rates during baseline and followup date $(F$-statistic $=40.67, p$-value $=0.01)$. Intensive monitoring proves as effective for female as well as for male entrepreneurs $(F$-statistic $=0.59, p$-value $=0.44)$.

\section{Conclusions and discussion}

Using objective data on loan repayments of MFI microfinance debtors, the present paper empirically examines the extent to which entrepreneurship training and intensive monitoring programmes improve loan repayment rates for microfinance debtors 


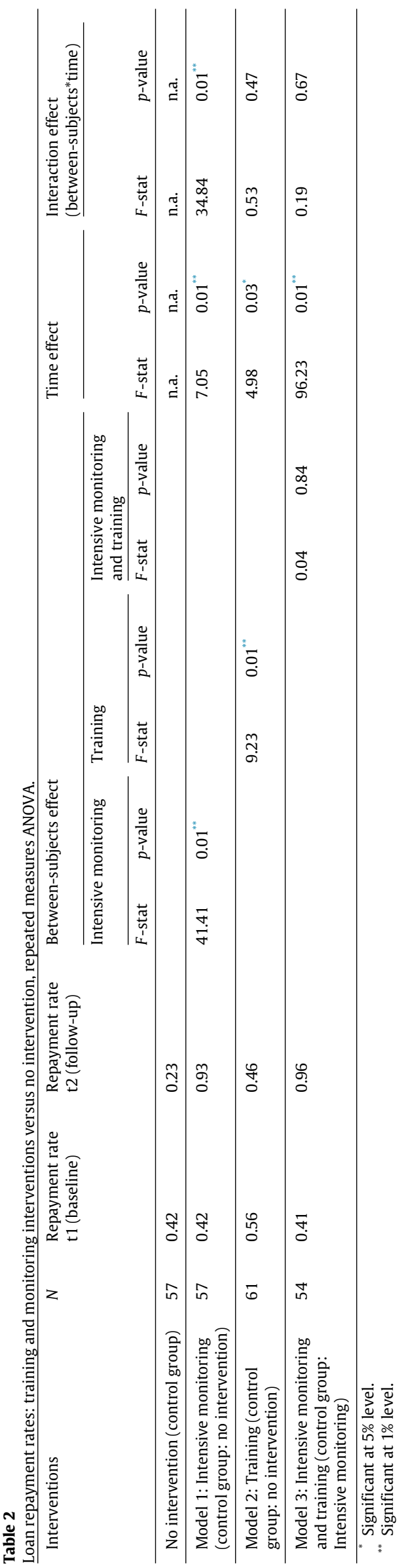


28

D. Agbeko et al. / Journal of Behavioral and Experimental Finance 14 (2017) 23-29

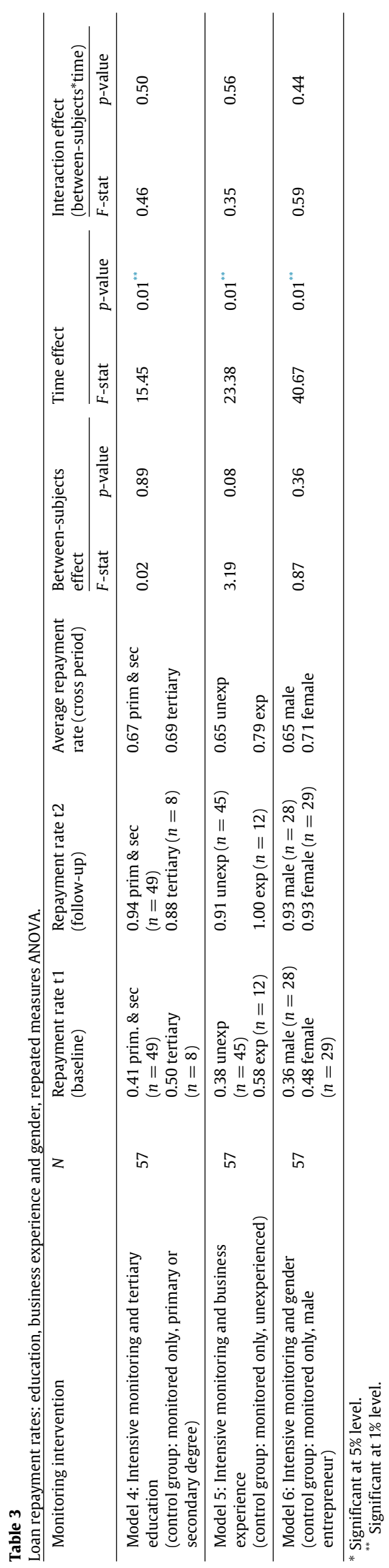


in developing countries. We compare baseline loan repayment data with one and half year follow-up data for 229 microfinance debtors, after having introduced monitoring interventions for 57 debtors, training interventions for 61 debtors and both training and monitoring interventions for 54 debtors.

Entrepreneurship training programmes also fail to improve loan repayment rates. This result is consistent with Karlan and Valdivia (2011) and McKenzie and Woodruf's (2012) failure to empirically establish any causality between training and loan repayment performance. Contrary to the findings of Kuzilwa (2005), training programmes do not add to the effectiveness of monitoring interventions. The absence of any impact from training on repayment performance is consistent with Yunus' (1999) argument that entrepreneurial skills are innate and therefore cannot be trained.

MFIs typically monitors its debtors four times per year. Results show that those debtors monitored four times per year systematically decrease their repayment rates over time. This result suggests that moderately intensive monitoring programmes fail to improve loan repayment rates. Intensive monitoring programmes successfully improve loan repayment rates. Relative to those microfinance debtors monitored only four times per year, those monitored intensively significantly improve repayment performance. Intensive monitoring is equally effective for highly and poorly educated, experienced and unexperienced, female and male microfinance debtors: MFIs may significantly improve repayment rates should they consistently monitor their microfinance debtors intensively. Intensive monitoring programmes are labour intensive and therefore costly. Further research should focus on cost-benefit analyses of intensive monitoring programmes from the perspective of the MFI.

\section{Appendix A. Supplementary data}

Supplementary material related to this article can be found online at http://dx.doi.org/10.1016/j.jbef.2017.03.002.

\section{References}

Alby, P., Auriol, E., Nguimkeu, P., 2011. Social barriers to entrepreneurship in Africa: the forced mutual help hypothesis.

Anthony, D., Horne, C., 2003. Gender and cooperation: explaining loan repayment in micro-credit groups. Social Psychol. Quarter. 293-302.

Balogun, E., Alimi, A., 1988. Loan delinquency among small farmers in developing countries: A case study of the small-farmer credit programme in Lagos state of Nigeria. CBN Econ. Financ. Rev. 26 (3).

Baron, R.A., Ensley, M.D., 2006. Opportunity recognition as the detection of meaningful patterns: Evidence from comparisons of novice and experienced entrepreneurs. Manage. Sci. 52 (9), 1331-1344.

Baum, J.R., Locke, E.A., 2004. The relationship of entrepreneurial traits, skill, and motivation to subsequent venture growth. J. Appl. Psychol. 89 (4), 587

Becker, G.S., 1993. Nobel lecture: The economic way of looking at behavior. J. Polit. Econ. 385-409.

Behr, P., Entzian, A., Guettler, A., 2011. How do lending relationships affect access to credit and loan conditions in microlending? J. Bank. Fin. 35 (8), 2169-2178.

Bichanga, W., Aseyo, L., 2013. Causes of loan default within micro finance institutions in Kenya. Interdiscip. J. Contemp. Res. Bus. 4 (12), 316-335.

Chandler, G.N., Jansen, E., 1992. The founder's self-assessed competence and venture performance. J. Bus. Ventur. 7 (3), 223-236.

Chen, C.C., Greene, P.G., Crick, A., 1998. Does entrepreneurial self-efficacy distinguish entrepreneurs from managers? J. Bus. Ventur. 13 (4), 295-316

Echtner, C.M., 1995. Entrepreneurial training in developing countries. Ann. Tourism Res. 22 (1), 119-134.

Edgcomb, E.L., 2002. What makes for effective microenterprise training? J. Microfinance/ESR Rev. 4 (1), 99-114.

Ekpe, I., Mat, N.B., Razak, R.C., 2010. The effect of microfinance factors on women entrepreneurs' performance in Nigeria: A conceptual framework. Int. J. Bus. Soc. Sci. 1 (2), 255-263.

Elaine, E., Barton, L., 1998. Social intermediation and microfinance programmes: A literature review. USA: Micro-Enterprises Best Practices.

Godquin, M., 2004. Microfinance repayment performance in Bangladesh: How to improve the allocation of loans by MFIs. World Dev. 32 (11), 1909-1926.
Idris, A.J., Agbim, K.C., 2015. Effect of social capital on poverty alleviation: A study of women entrepreneurs in Nasarawa State, Nigeria. J. Res. Nat. Dev. 13 (1), $208-222$.

Karlan, D., Valdivia, M., 2011. Teaching entrepreneurship: Impact of business training on microfinance clients and institutions. Rev. Econ. Stat. 93 (2), 510-527. http://dx.doi.org/10.1162/Rest_a_00074.

Kabeer, N., 2001. Conflicts over credit: re-evaluating the empowerment potential of loans to women in rural Bangladesh. World Develop. 29 (1), 63-84.

Karnani, A.G., 2007. Employment, not microcredit, is the solution. Ross School of Business Paper(1065).

Kevane, M., Wydick, B., 2001. Microenterprise lending to female entrepreneurs: Sacrificing economic growth for poverty alleviation? World Develop. 29 (7), $1225-1236$.

Kohansal, M.R., Mansoori, H., 2009. Factors affecting on loan repayment performance of farmers in Khorasan-Razavi province of Iran. Paper presented at the Conference on International Research on Food Security, Natural Resource Management and Rural Development, University of Hamburg.

Kraiger, K., Ford, J.K., Salas, E., 1993. Application of cognitive, skill-based, and affective theories of learning outcomes to new methods of training evaluation. J. Appl. Psychol. 78 (2), 311.

Kuzilwa, J.A., 2005. The role of credit for small business success a study of the national entrepreneurship development fund in tanzania. J. Entrepreneurship 14 (2), 131-161

Lans, T., Blok, V., Gulikers, J., 2015. Show me your network and I'll tell you who you are: social competence and social capital of early-stage entrepreneurs. Entrepreneurship \& Regional Develop. 27 (7-8), 458-473.

Ledgerwood, J., 1999. Microfinance Handbook: An Institutional and Financial Perspective. World Bank, Washington.

Lensink, R., Mersland, R., Nhung, V.T.H., 2011. Should microfinance institutions specialize in financial services. Paper presented at the Second international research conference on microfinance, Groningen, The Netherlands.

Mano, Y., Iddrisu, A., Yoshino, Y., Sonobe, T., 2012. How can micro and small enterprises in Sub-Saharan Africa become more productive? The impacts of experimental basic managerial training. World Develop. 40 (3), 458-468.

Martin, B.C., McNally, J.J., Kay, M.J., 2013. Examining the formation of human capital in entrepreneurship: A meta-analysis of entrepreneurship education outcomes. J. Bus. Ventur. 28 (2), 211-224.

McKenzie, D.J., Woodruff, C., 2012. What are We Learning from Business Training and Entrepreneurship Evaluations around the Developing World? Vol. 6202. World Bank, Development Research Group, Finance and Private Sector Development Team.

Mensah, C., Raphael, G., Dorcas, O., Kwadwo, B.Y., 2013. The relationship between loan default and repayment schedule in microfinance institutions in ghana: A case study of sinapi aba trust. Res. J. Finance Account. 4 (19), 165-175.

Mirpourian, S., Caragliu, A., Di Maio, G., Rusinà, E., Landoni, P., 2015. Determinants of Loan Repayment Performance Among Borrowers of Microfinance Institutions: Evidence from India. Available at SSRN 2593158.

Mutisya, E., Yarime, M., 2014. Microcredit for the Development of the Bottom of the Pyramid Segment: Impact of Access to Financial Services on Microcredit Clients, Institutions and Urban Sustainability.

Newman, A., Schwarz, S., Borgia, D., 2014. How does microfinance enhance entrepreneurial outcomes in emerging economies? The mediating mechanisms of psychological and social capital. Int. Small Bus. J. 32 (2), 158-179.

Oosterbeek, H., Van Praag, M., Ijsselstein, A., 2010. The impact of entrepreneurship education on entrepreneurship skills and motivation. European Econom. Rev. 54 (3), 442-454

Otero-Neira, C., Arias, M.J.F., Lindman, M.T., 2013. Market orientation and entrepreneurial proclivity: antecedents of innovation. Global Bus. Rev. 14 (3), 385-395.

Ployhart, R.E., Moliterno, T.P., 2011. Emergence of the human capital resource: A multilevel model. Acad. Manage. Rev. 36 (1), 127-150.

Pronyk, P.M., Kim, J.C., Abramsk, T., Phetla, G., Hargreaves, J.R., Morison, L.A., Porter, J.D.H., et al., 2008. A combined microfinance and training intervention can reduce HIV risk behaviour in young female participants. Aids 22 (13), 1659-1665

Rahman, A., 1999. Women and Microcredit in Rural Bangladesh: Anthropological Study of the Rhetoric and Realities of Grameen Bank Lending. Westview Press, Inc.

Ridgeway, C.L., Smith-Lovin, L., 1999. The gender system and interaction. Ann. Rev. Sociol. 191-216.

Smith, E., Perks, S., 2006. Training interventions needed for developing black microentrepreneurial skills in the informal sector: A qualitative perspective. SA J. Human Res. Manage. 4 (1), 17-26.

Ucbasaran, D., Westhead, P., Wright, M., 2008. Opportunity identification and pursuit: does an entrepreneur's human capital matter? Small Bus. Econ. 30 (2), $153-173$.

Van Dyk, P.S., Nel, P.S., van Zyl Loedolff, P., 1992. Training management: a multidisciplinary approach to human resources development in Southern Africa. Southern Book Publishers.

Verhees, F.J., Lans, T., Verstegen, J.A., 2012. The influence of market and entrepreneurial orientation on strategic marketing choices: the cases of Dutch farmers and horticultural growers. J. Chain Network Sci. 12 (2), 167-179.

Wiklund, J., Patzelt, H., Shepherd, D.A., 2009. Building an integrative model of small business growth. Small Bus. Econ. 32 (4), 351-374.

Yunus, M., 1999. The grameen bank. Sci. Am. 281 (5), 114-119. 